\title{
Electrochemical Characterization of a PEMEC Using Impedance Spectroscopy
}

Elsøe, Katrine; Grahl-Madsen, L.; Hjelm, Johan; Scherer, G.G.; Hjelm, Johan; Mogensen, Mogens Bjerg

Published in:

Journal of The Electrochemical Society

Link to article, DOI:

10.1149/2.0651713jes

Publication date:

2017

Document Version

Publisher's PDF, also known as Version of record

Link back to DTU Orbit

Citation (APA):

Elsøe, K., Grahl-Madsen, L., Hjelm, J., Scherer, G. G., Hjelm, J., \& Mogensen, M. B. (2017). Electrochemical Characterization of a PEMEC Using Impedance Spectroscopy. Journal of The Electrochemical Society, 164(13), F1419-F1426 . https://doi.org/10.1149/2.0651713jes

\section{General rights}

Copyright and moral rights for the publications made accessible in the public portal are retained by the authors and/or other copyright owners and it is a condition of accessing publications that users recognise and abide by the legal requirements associated with these rights.

- Users may download and print one copy of any publication from the public portal for the purpose of private study or research.

- You may not further distribute the material or use it for any profit-making activity or commercial gain

- You may freely distribute the URL identifying the publication in the public portal 


\title{
Electrochemical Characterization of a PEMEC Using Impedance Spectroscopy
}

\author{
K. Elsøe, $\circledast^{a, z}$ L. Grahl-Madsen, ${ }^{b}$ G. G. Scherer, ${ }^{\mathrm{c}}$ J. Hjelm, $\circledast^{\mathrm{a}, *}$ and M. B. Mogensen $\circledast^{\mathrm{a}, * *}$ \\ ${ }^{a}$ Department of Energy Conversion and Storage, Technical University of Denmark, 4000 Roskilde, Denmark \\ ${ }^{b}$ EWII Fuel Cells A/S, 5220 Odense SE, Denmark \\ c5232 Hägglingen, Switzerland
}

\begin{abstract}
In this study, electrochemical impedance spectroscopy (EIS) is applied in combination with cyclic voltammetry (CV) and curren density - cell voltage curves (iV-curves) to investigate the processes contributing to the total impedance of a polymer electrolyte membrane electrolysis cell (PEMEC). iV-curves were linear above $0.35 \mathrm{~A} \mathrm{~cm}^{-2}$ implying ohmic processes to be performance limiting, however the impedance spectra showed three arcs indicating three electrochemical reactions at these conditions not to be purely ohmic, but also to have capacitive properties. A hypothesis that the composite $\mathrm{IrO}_{\mathrm{x}} / \mathrm{Nafion}$ anode catalyst layer causes two of these arcs with a constant sum of resistance and current constrictions cause the third arc, is suggested. This hypothesis implies that the total differential cell resistance at current densities above $0.35 \mathrm{~A} \mathrm{~cm}^{-2}$ is purely ascribed to protonic resistance in Nafion in this type of PEMEC. (C) The Author(s) 2017. Published by ECS. This is an open access article distributed under the terms of the Creative Commons Attribution 4.0 License (CC BY, http://creativecommons.org/licenses/by/4.0/), which permits unrestricted reuse of the work in any medium, provided the original work is properly cited. [DOI: 10.1149/2.0651713jes] All rights reserved.

(cc) BY
\end{abstract}

Manuscript submitted May 11, 2017; revised manuscript received September 25, 2017. Published October 11, 2017

The interest in renewable electrical energy obtained from e.g. wind turbines and solar cells have increased over the past years. However, the demand of electrical energy from society does not always correlate with the renewable electrical energy production, and a method to store the excess electrical energy for later use is needed. One such method is electrolysis of water into hydrogen and thus converts electrical energy into chemical energy bound in the hydrogen molecules, and thereby the energy can be stored. PEMECs have the ability to operate at high current densities, which reduces the operation costs. ${ }^{1}$ The highest possible operation current density for a PEMEC at a given potential is i.a. depending on its internal resistance, i.e. a cell resistance as low as possible is preferred. The total cell resistance is given by the iV-curve, but multiple processes within the PEMEC may contribute to this. In order to resolve these processes, EIS should be applied, as this can resolve the time constants of the single processes. ${ }^{2}$ It should be noted that the total cell resistance measured by EIS for a given point $(\mathrm{i}, \mathrm{V})$ is equal to the slope of the $\mathrm{iV}$-curve in this point in case of steady state conditions. It should further be noted that a single EIS spectrum cannot be interpreted on its own, but has to be combined with either substantial pre-knowledge of the system, or with a series of experiments in which relevant physical and chemical parameters are varied systematically. ${ }^{3}$ Furthermore, EIS has to be complemented by other methods; measurements of iV-curves and CV are such methods.

Within PEMEC research, EIS is so far primarily applied to determine the electrolyte resistance, which is frequently used for ohmic drop corrections of iV-curves. ${ }^{4-12}$ However, some research groups such as Rozain et al., ${ }^{13,14}$ Lettenmeier et al. ${ }^{15}$ and Siracusano et al. ${ }^{5,16}$ among others have studied EIS of PEMECs in further detail, but most often at low current densities in the activation region of the iV-curve, where the oxygen evolution reaction (OER) current density is very low. ${ }^{5-8,13,14,16,17}$ Only a few research groups have reported EIS measured at higher current densities in the linear region of the iV-curve during the OER.$^{6-8}$ The EIS data is often fitted to an empirical equivalent circuit consisting of a serial resistance and one or two arcs reported to originate from the anode, or from the cathode and the anode. Sometimes diffusion elements are added to the equivalent circuit as well. ${ }^{7-8,14-16}$ Detailed impedance studies of the PEMEC anode catalyst material, $\mathrm{IrO}_{\mathrm{x}}$, by the application of model electrodes are also found in literature, e.g. as reported by Papaderakis et al. ${ }^{4}$

The work in this article is a technological unravelling investigating performance limitation in PEMECs operating at high current densities. It presents a hypothesis suggesting, which physical processes that are primarily contributing to the total cell impedance of a PEMEC

\footnotetext{
*Electrochemical Society Member.

**Electrochemical Society Fellow.

${ }^{\mathrm{z} E-m a i l: k a t e l @ d t u . d k}$
}

based on findings from EIS measurements at various temperatures and current densities in combination with $\mathrm{CV}, \mathrm{iV}$-curves and scanning electron microscopy (SEM). The suggested hypothesis deviates from equivalent circuits reported in the literature so far.

\section{Experimental}

Materials and setup.-The PEMECs examined in this study are benchmark PEMECs from the Danish company EWII Fuel Cells A/S. The cells have an active electrode area of $2.89 \mathrm{~cm}^{2}$ and contain a Nafion 117 membrane. A schematic drawing of the PEMEC mounted in a cell house, likewise provided by EWII Fuel Cells A/S, can be found in Figure 1. The anode is loaded with $0.3 \mathrm{mg} \mathrm{cm}^{-2} \mathrm{IrO}_{\mathrm{x}}$ catalyst with Nafion binder and $2.7 \mathrm{mg} \mathrm{cm}{ }^{-2}$ Ir metal, likewise with Nafion binder, titanium felt is used as current collector and the anode flow plate is made of titanium. In this regard, it should be noted that the Ir metal layer functions as a current collector insuring electrical contact between the $\mathrm{IrO}_{\mathrm{x}}$ catalyst layer and the titanium felt. The Ir metal layer is stated not to be electrochemical active by EWII Fuel Cells A/S. This is probably due to the low surface area of the Ir metal particles compared to the $\mathrm{IrO}_{\mathrm{x}}$ particles c.f. the SEM images in Figure 7. The cathode contains $0.5 \mathrm{mg} \mathrm{cm}{ }^{-2}$ platinum supported on carbon, carbon felt is used as current collector and the cathode flow plate is made of carbon. Gold coated copper current collectors are applied at both electrodes and the cell housing is made of stainless steel. The water inlet and the water outlet are sealed with nitrile O-rings at the current collectors and an EPDM O-ring is applied as sealing at the flow plate on the cathode. The cell temperature was measured with a Pt100 thermoresistor mounted in the stainless steel cell housing close to the water inlet.

Electrochemical characterization.-A PEMEC was characterized with $\mathrm{CV}$ at $61^{\circ} \mathrm{C}$ and ambient pressure while flushing the cathode with $10 \mathrm{~mL} \mathrm{~min}{ }^{-1}$ hydrogen with $3 \mathrm{vol}$. \% humidity (the temperature of the $\mathrm{mQ}$ water in the bubble flask was $26^{\circ} \mathrm{C}$ ). The potential of the cathode is assumed to be close to $0 \mathrm{~V}$ vs. the standard hydrogen electrode (SHE) at open circuit voltage (OCV), since the cathode consists of platinum with pure hydrogen in an acidic environment due to the Nafion membrane. We are aware of the problem that the $\mathrm{pH}$ of Nafion in the $\mathrm{H}_{2}$ electrode is not well-known. ${ }^{1,18,19}$ It is known that the kinetics of this type of $\mathrm{Pt} / \mathrm{H}_{2}$ electrode are very fast compared to the kinetics of the $\mathrm{IrO}_{\mathrm{x}}$ anode, meaning that the primary part of the total cell polarization resistance arise from the anode and not the $\mathrm{Pt} / \mathrm{H}_{2}$ electrode. ${ }^{20-22}$ Approximately $400 \mathrm{~mL} \mathrm{~min}^{-1}$ nitrogen saturated $\mathrm{mQ}$ water was supplied to the anode. The cathode was counter and reference electrode, and the anode was the working electrode. CVs were recorded in the potential range $0.00-1.40 \mathrm{~V}$ and seven cycles 

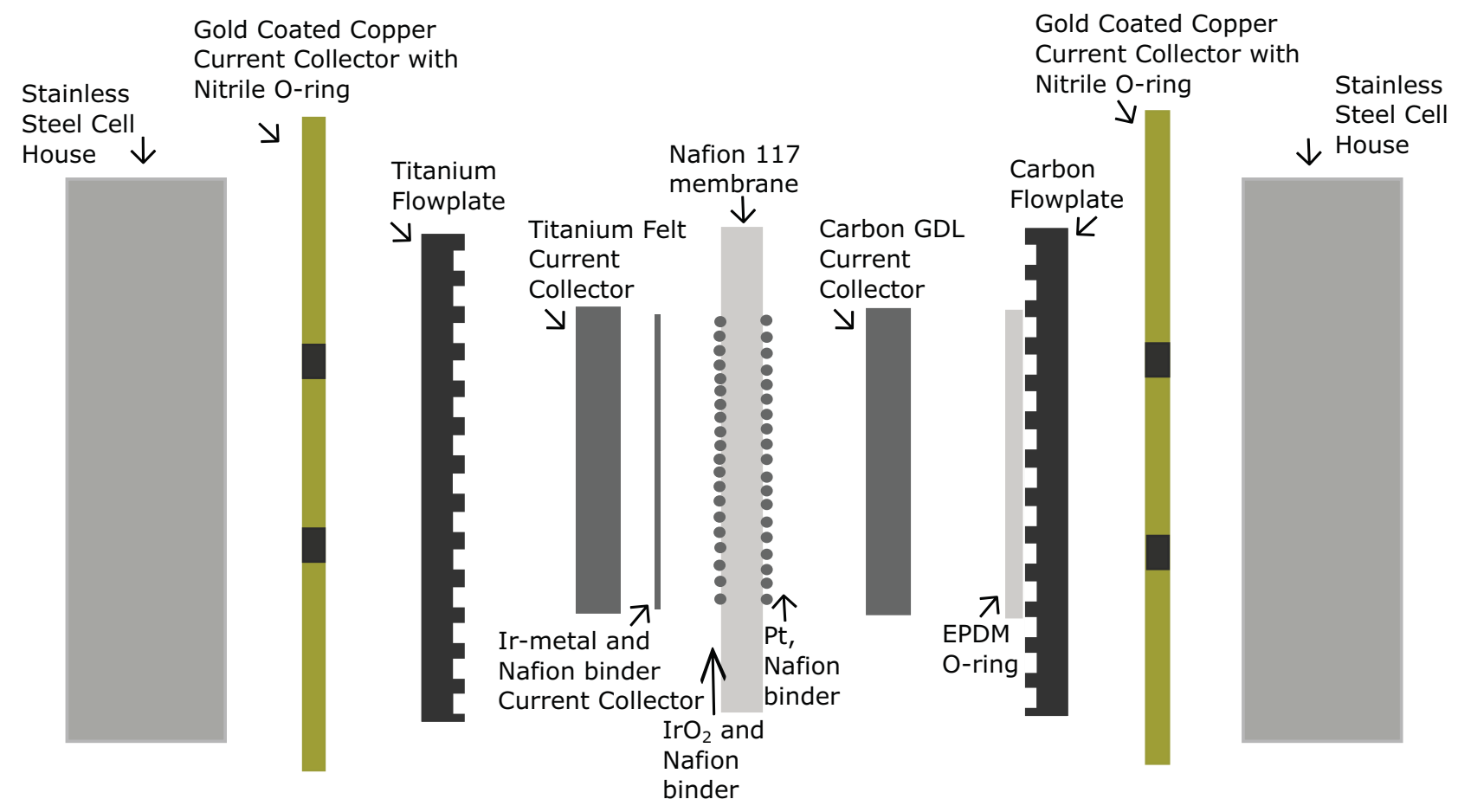

Figure 1. Schematic drawing of the PEMEC test setup provided by EWII Fuel Cells A/S.

were recorded with a sweep rate of $50 \mathrm{mV} \mathrm{s}^{-1}$. The main purpose of the $\mathrm{CV}$ measurements was to use the position of the $\mathrm{IrO}_{\mathrm{x}}$ redox peaks, which are known from the literature, to check if the assumption that the $\mathrm{H}_{2} / \mathrm{Pt} / \mathrm{Nafion}$ electrode potential is close to the SHE potential.

iV-curves and EIS were measured galvanostatically on another benchmark PEMEC from EWII Fuel Cells A/S similar to the PEMEC applied for the CV measurements. The measurements were conducted at potentials above the OER potential and at ambient pressure. No gases were supplied to the electrodes, and approximately $450 \mathrm{~mL} \min ^{-1} \mathrm{mQ}$ water aerated with atmospheric air was supplied to the anode. A Delta Elektronika ES 015-10 power supply, with an accuracy of $\pm 0.08 \%$ in constant current mode on the potential and current measurements, respectively, was applied for cell polarization. A Solartron 1260 impedance analyzer was used for the impedance data acquisition, and a $50 \mathrm{~m} \Omega$ shunt resistance was serially connected to the cell for exact DC current determination. iV-curves were measured at 53,61 and $69^{\circ} \mathrm{C}$ from $0.050 \mathrm{~A} \mathrm{~cm}^{-2}$ to $1.000 \mathrm{~A} \mathrm{~cm}^{-2}$ with current steps of $50 \mathrm{~mA}$ and 20 seconds between each current step. Furthermore, the cell was operated at 0.07, 0.35, 0.69 and $1.00 \mathrm{~A} \mathrm{~cm}^{-2}$ at 53, 61 and $69^{\circ} \mathrm{C}$ while examined with EIS. The cell was conditioned for 20 minutes at each current step and for 1 hour at each temperature prior to EIS measurements. The frequency range was $100 \mathrm{kHz}-0.01$ $\mathrm{Hz}$, the alternating current (AC) amplitude was $24.5 \mathrm{~mA} \mathrm{~cm}{ }^{-2}$, and 12 points were measured per decade.

All impedance data in this study has been analyzed and plotted using the impedance software Ravdav. ${ }^{23}$

Morphology of pristine and used PEMEC MEAs.-The microstructures of a pristine benchmark PEMEC from EWII Fuel Cells $\mathrm{A} / \mathrm{S}$ and a used benchmark PEMEC from EWII Fuel Cells A/S tested at various temperatures and current densities as described above were examined with SEM. The microscope used for examination of the pristine PEMEC was a Zeiss Supra 35 with a field emission gun and a backscatter detector. An acceleration voltage of $10 \mathrm{kV}$ was applied for imaging. A cross section of the pristine PEMEC was prepared for SEM examination by cutting the PEMEC with a scalpel followed by ion milling with argon atoms for 18 hours in an E-3500 ion milling system from Hitachi with an acceleration voltage of $6 \mathrm{kV}$. Cross sections of the used PEMEC were prepared by cutting the sample with a scalpel. The used PEMEC was examined with a Zeiss Merlin microscope with a field emission gun and a backscatter detector. An acceleration voltage of $15 \mathrm{kV}$ was applied for imaging the used PEMEC. Both the SEM sample of the pristine and of the used PEMEC were coated with 10-20 nm carbon prior to SEM examination. Due to difficulties getting sharp SEM images at high magnification and being able to observe the microstructure of the anode, the ion milled pristine PEMEC was further studied using a focused ion beam (FIB) SEM CrossBeamTM 1540 XB (Carl Zeiss AG). A small cross section of the Ir metal layer, $\mathrm{IrO}_{\mathrm{x}}$ anode catalyst layer and some Nafion membrane was cut with a $30 \mathrm{kV}$ and $20 \mathrm{pA}$ FIB, and an acceleration voltage of $2 \mathrm{kV}$ was applied for imaging in order to avoid charging of the uncoated Nafion membrane during imaging.

\section{Results}

Redox properties of the oxygen evolution electrode.-Figure 2 depicts a CV of a PEMEC. Since the cathode is flushed with hydrogen, and only nitrogen saturated mQ water is supplied to the anode, only the redox properties of the anode should be displayed in the $\mathrm{CV}$ in Figure 2. The CV depicted in Figure 2 shows a redox peak at $0.77 \mathrm{~V}$, a redox peak at $1.23 \mathrm{~V}$ and a sharp increase in the anodic current at $1.40 \mathrm{~V}$, which is due to OER. ${ }^{4,13,24}$ The CV does almost not have any slope at $0.07-0.40 \mathrm{~V}$, which suggests that no faradaic reaction is taking place at these potentials. At $0.00 \mathrm{~V}$ to approximately $0.07 \mathrm{~V}$ negative currents that originate from hydrogen evolution on the Ir-electrode (the anode at higher potentials) are observed in the CV.

Cell performance.- $\mathrm{iV}$-curves measured at 53,61 and $69^{\circ} \mathrm{C}$ of a benchmark PEMEC are shown in Figure 3. It is seen that the cell has the better performance, the higher the operating temperature, and that all three $\mathrm{iV}$-curves are linear above $0.35 \mathrm{~A} \mathrm{~cm}^{-2}$ implying constant total differential cell resistances above $0.35 \mathrm{~A} \mathrm{~cm}^{-2}$ at each temperature. The total differential cell resistances are determined to be 0.362 $\Omega \mathrm{cm}^{2}\left(\mathrm{R}^{2}=0.9987\right)$ at $53^{\circ} \mathrm{C}, 0.318 \Omega \mathrm{cm}^{2}\left(\mathrm{R}^{2}=0.9992\right)$ at $61^{\circ} \mathrm{C}$ and $0.307 \Omega \mathrm{cm}^{2}\left(\mathrm{R}^{2}=0.9991\right)$ at $69^{\circ} \mathrm{C}$ from the slopes of the linear part of the three $\mathrm{iV}$-curves. 


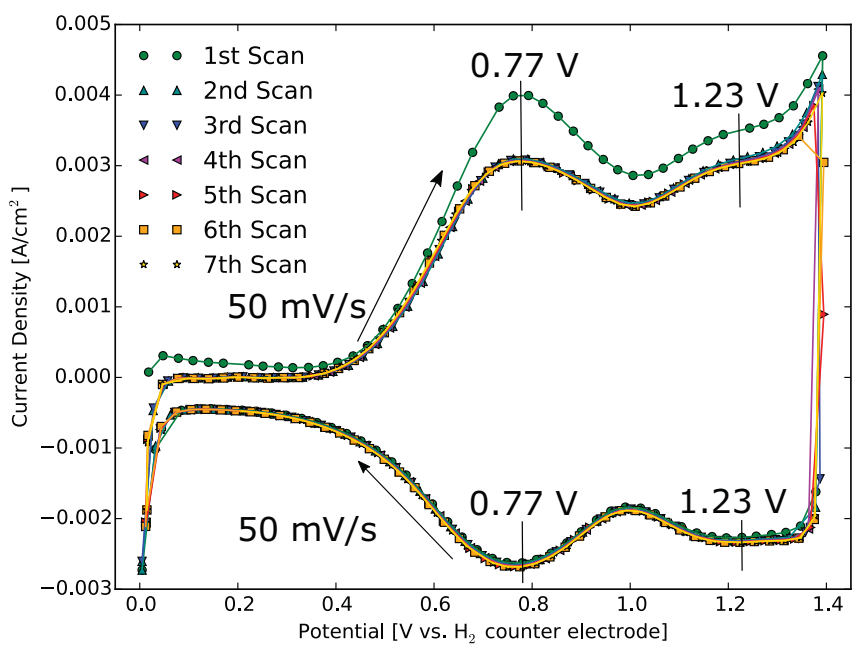

Figure 2. CV measured on a PEMEC showing seven cycles obtained with a sweep rate of $50 \mathrm{mV} \mathrm{s}^{-1}$ at $61^{\circ} \mathrm{C}$ and ambient pressure. The cathode consisted of platinum flushed with $10 \mathrm{~mL} \mathrm{~min}^{-1}$ moisturized hydrogen with 3 vol. \% humidity. The anode was flushed with $400 \mathrm{~mL} \mathrm{m^{-1 }}$ nitrogen saturated mQ water. These experimental conditions imply that only the redox properties of the anode catalyst are displayed in the CV.

Influence of temperature and operating voltage / current density on cell impedance.- Nyquist plots of EIS measured on a PEMEC operated at $0.07,0.35,0.69$ and $1.00 \mathrm{~A} \mathrm{~cm}^{-2}$ and at 53,61 and $69^{\circ} \mathrm{C}$ are shown in Figure 4. EIS data at $50-80 \mathrm{~Hz}$ is left out due to noise from the electrical grid. It should be noted that $-Z_{\mathrm{im}}$ is a positive number due to negative $Z_{\mathrm{im}}$ values. It is seen that the shape of the Nyquist plots at each current density is the same no matter the operating temperature. Figure 5 shows Nyquist plots of only the EIS data measured at $61{ }^{\circ} \mathrm{C}$ at the four current densities. In this figure it might be easier to notice the changes in EIS with changes in current density, and the changes are representative for all three temperatures. The Nyquist plot of EIS measured at $0.07 \mathrm{~A} \mathrm{~cm}^{-2}$ shows a very significant arc, and a small arc at very low frequencies overlapped by the large arc. An increase in $-Z_{\mathrm{im}}$ is observed at the highest frequencies. The real part of the

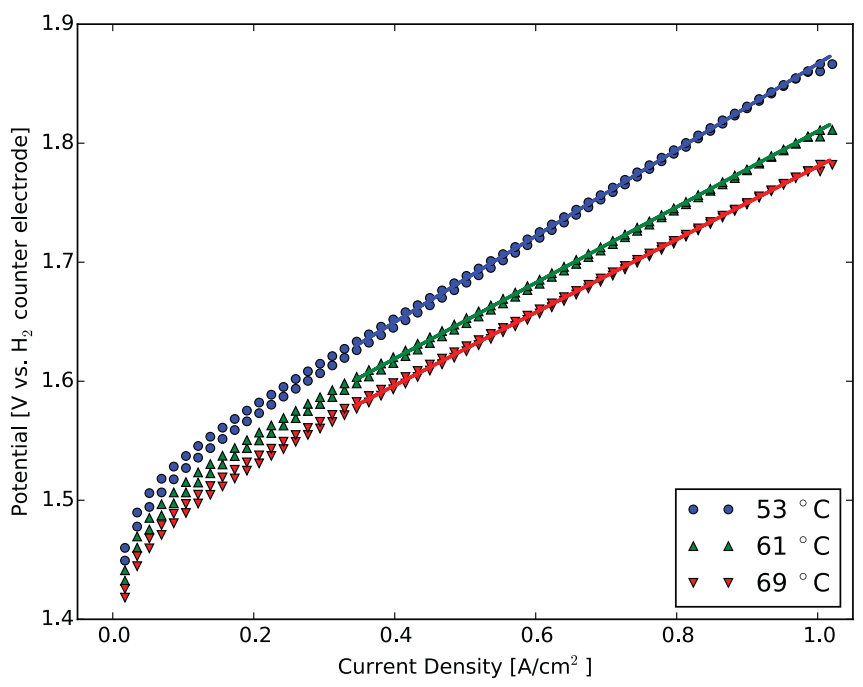

Figure 3. iV-curves for a PEMEC measured at 53,61 and $69^{\circ} \mathrm{C}$. The iV-curves are measured with ambient conditions at the cathode while flushing the anode with $450 \mathrm{~mL} \mathrm{~min}^{-1}$ aerated $\mathrm{mQ}$ water at ambient pressure. Linear regressions of the linear part of the iV-curves at current densities above $0.35 \mathrm{~A} \mathrm{~cm}^{-2}$ are depicted in the graphs, and total cell polarization resistances of $0.362 \Omega \mathrm{cm}^{2}$ $\left(\mathrm{R}^{2}=0.9987\right), 0.318 \Omega \mathrm{cm}^{2}\left(\mathrm{R}^{2}=0.9992\right)$ and $0.307 \Omega \mathrm{cm}^{2}\left(\mathrm{R}^{2}=0.9991\right)$ are determined from the slopes of the iV-curves at 53,61 and $69^{\circ} \mathrm{C}$, respectively.
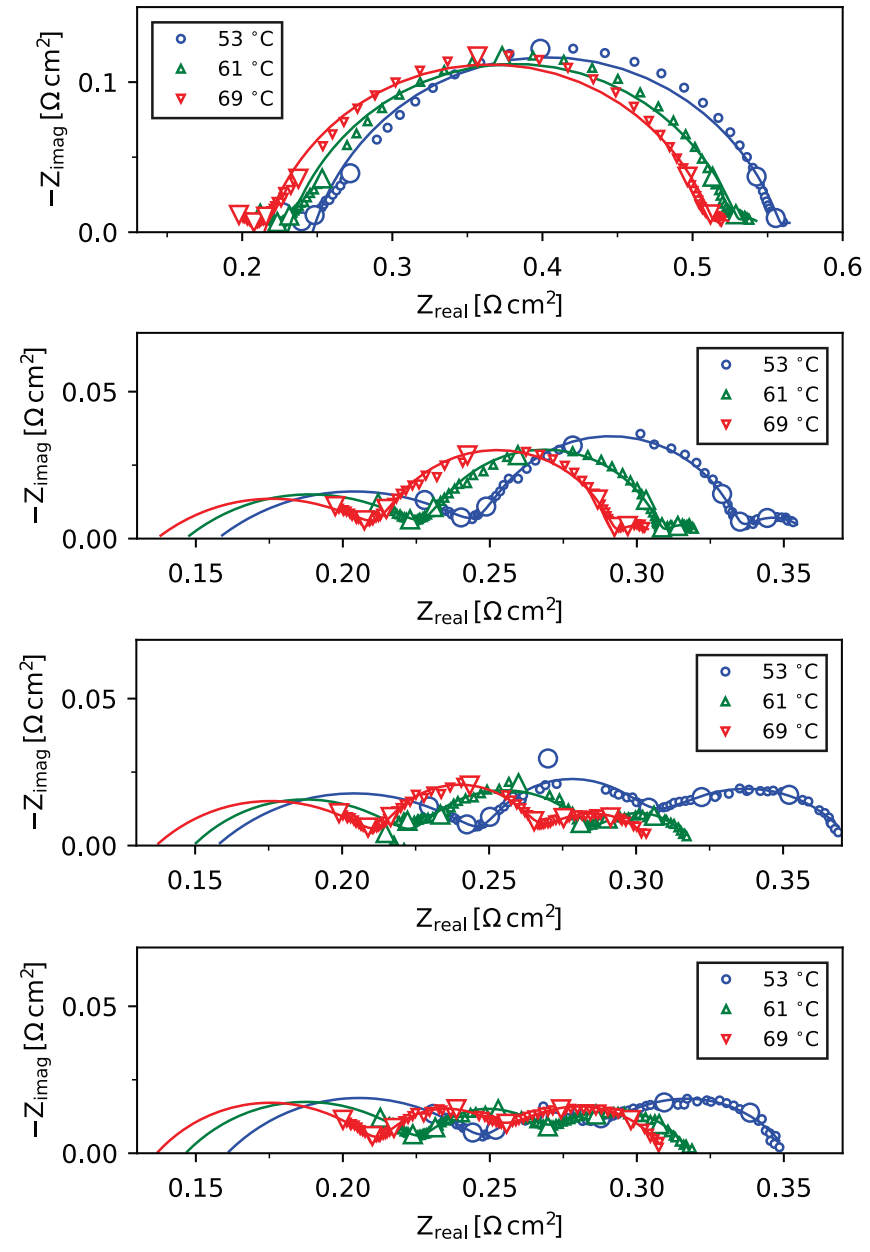

Figure 4. Nyquist representations of EIS and fits of a PEMEC operated at 53 , 61 and $69^{\circ} \mathrm{C}$ at 0.07 (a), 0.35 (b), 0.69 (c) and 1.00 (d) $\mathrm{A} \mathrm{cm}^{-2}$ and at ambient pressure. $450 \mathrm{~mL} \mathrm{~min}^{-1}$ aerated $\mathrm{mQ}$ water was supplied to the anode during operation with no gas supply to any of the electrodes as moisturized $\mathrm{H}_{2}$ and $\mathrm{O}_{2}$ are formed during electrolysis. EIS measured at $100 \mathrm{kHz}, 10 \mathrm{kHz}, 1 \mathrm{kHz}, 100$ $\mathrm{Hz}, 10 \mathrm{~Hz}, 1 \mathrm{~Hz}$ and $0.1 \mathrm{~Hz}$ are marked with bigger signs in each spectrum. An $\mathrm{R}-\mathrm{R}_{1} \mathrm{Q}_{1}-\mathrm{R}_{2} \mathrm{Q}_{2}$ equivalent circuit was used to determine summit frequencies of the arcs at $0.07 \mathrm{~A} \mathrm{~cm}^{-2}$ above $5000 \mathrm{~Hz}$, and an $\mathrm{R}-\mathrm{R}_{1} \mathrm{Q}_{1}-\mathrm{R}_{2} \mathrm{Q}_{2}-\mathrm{R}_{3} \mathrm{Q}_{3}$ equivalent circuit was used to determine summit frequencies of arcs at $0.35-1.00 \mathrm{~A} \mathrm{~cm}^{-2}$. The middle frequency arc had summit frequencies at 9.06-9.49 Hz, 63.2-67.2 $\mathrm{Hz}, 88.8-131.7 \mathrm{~Hz}$ and $118.6-143.9 \mathrm{~Hz}$ at $0.07,0.35,0.69$ and $1.00 \mathrm{~A} \mathrm{~cm}^{-2}$, respectively. The low frequency arc has summit frequencies of $0.010-0.017$ $\mathrm{Hz}, 0.040-0.053 \mathrm{~Hz}, 0.179-0.273 \mathrm{~Hz}$ and $0.464-0.480 \mathrm{~Hz}$ at $0.07,0.35,0.69$ and $1.00 \mathrm{~A} \mathrm{~cm}^{-2}$, respectively. EIS data at $50-80 \mathrm{~Hz}$ is left out due to noise from the electrical grid.

impedance at the local minimum of $-\mathrm{Z}_{\mathrm{im}}$ at the high frequencies is

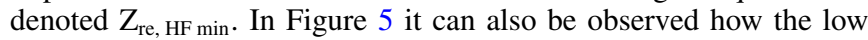
frequency arc increases with increasing current density, and how the arc at the middle frequencies decreases with increasing current density, and the increase in $-Z_{i m}$ at the highest frequencies are observed at all four current densities.

Morphology of pristine and used PEMEC MEAs.-Figure 6 and 7 show SEM images of cross sections of a pristine PEMEC, a used PEMEC and a zoom of the anode of the pristine PEMEC. A layer of $\mathrm{IrO}_{\mathrm{x}}$ catalyst with Nafion binder is observed on the Nafion membrane in the images of the pristine PEMEC. Ir metal particles in Nafion binder are seen on top of the $\mathrm{IrO}_{\mathrm{x}}$ catalyst layer in the pristine PEMEC, however in the SEM image of the used PEMEC it can be observed 

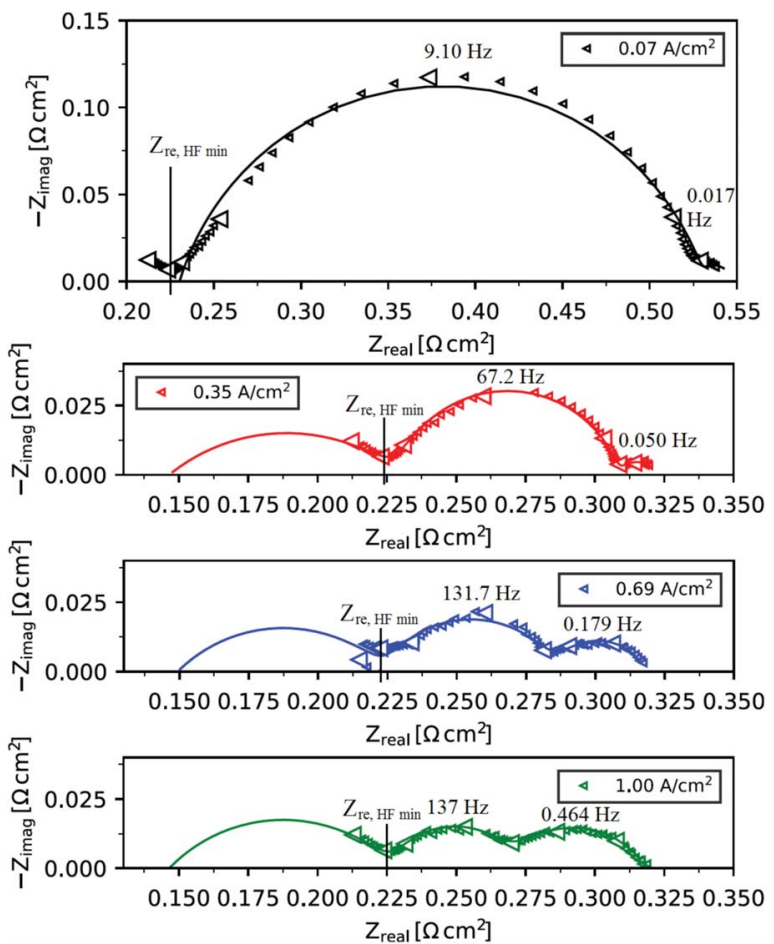

Figure 5. Nyquist representations and fits of EIS of a PEMEC operated at $0.07,0.35,0.69$ and $1.00 \mathrm{~A} \mathrm{~cm}^{-2}$ at $61{ }^{\circ} \mathrm{C}$ and ambient pressure. $450 \mathrm{~mL}$ $\mathrm{min}^{-1}$ aerated $\mathrm{mQ}$ water was supplied to the anode during operation with no gas supply to any of the electrodes as moisturized $\mathrm{H}_{2}$ and $\mathrm{O}_{2}$ are formed during electrolysis. EIS measured at $100 \mathrm{kHz}, 10 \mathrm{kHz}, 1 \mathrm{kHz}, 100 \mathrm{~Hz}, 10 \mathrm{~Hz}, 1 \mathrm{~Hz}$ and $0.1 \mathrm{~Hz}$ are marked with bigger signs in each spectrum. An $\mathrm{R}-\mathrm{R}_{1} \mathrm{Q}_{1}-\mathrm{R}_{2} \mathrm{Q}_{2}$ equivalent circuit was used to determine summit frequencies of the arcs at 0.07 $A c^{-2}$ above $5000 \mathrm{~Hz}$, and an $R-R_{1} Q_{1}-R_{2} Q_{2}-R_{3} Q_{3}$ equivalent circuit was used to determine summit frequencies at $0.35-1.00 \mathrm{~A} \mathrm{~cm}^{-2}$. EIS data at 50-80 $\mathrm{Hz}$ is left out due to noise at the electrical grid.

that the $\mathrm{IrO}_{\mathrm{x}}$ and $\mathrm{Ir}$ metal layers have been peeled off the membrane in some areas during detachment of the titanium felt after cell operation.

\section{Discussion}

Cathode potential close to the SHE potential.-The redox peaks in the CV depicted in Figure 2 are in Table I compared to redox peaks in $\mathrm{CV}$ s of $\mathrm{IrO}_{\mathrm{x}}$ model electrodes in PEMECs and in sulfuric acid media found in literature. From the comparison it can be seen that the redox peak potentials obtained from the CV in Figure 2 are very close to redox peak potentials reported for PEMECs at similar conditions and of the bare $\mathrm{IrO}_{\mathrm{x}}$, which imply that only the redox properties of the anode catalyst is seen in the CV. The redox peak at $0.77 \mathrm{~V}$ originates from the oxidation of $\mathrm{Ir}^{\mathrm{III}}$ to $\mathrm{Ir}^{\mathrm{IV}}$ and the redox peak at $1.23 \mathrm{~V}$ originates from the oxidation of $\mathrm{Ir}^{\mathrm{IV}}$ to $\mathrm{Ir}^{\mathrm{V}}$.4,13,24 This corroborates the assumption that the cathode potential - at least at low current density - is close to the SHE potential.

Ohmic resistances dominating above $0.35 \mathrm{~A} \mathrm{~cm}^{-2}$.- At potentials below $0.40 \mathrm{~V}$, the CV in Figure 2 has no slope and no current is flowing, meaning that at these low potentials, no faradaic reactions are taking place at the electrode, and the anode is said to be blocking. Only redox reactions in the $\mathrm{IrO}_{\mathrm{x}}$ catalyst material take place at these low potentials. However, above $1.20 \mathrm{~V}$ vs. SHE (at $61^{\circ} \mathrm{C}$ ) the electrode reaction rate increases (the polarization resistance decreases and oxygen evolves at the anode) fast with increasing potential, probably following the Butler-Volmer equation, until the current density reach a level, where the ohmic resistance becomes dominating. Ohmic resistances become totally dominating at current densities from $0.35 \mathrm{~A} \mathrm{~cm}^{-2}$, which is seen from the constant total cell resistance from $0.35 \mathrm{~A} \mathrm{~cm}^{-2}$ given in Table II and seen in Figure 4 and 5. The total cell resistance is the DC impedance, here obtained as the impedance at the lowest frequency at $0.01 \mathrm{~Hz}$. These findings are consistent with the iV-curves in Figure 3 measured at 53,61 and $69^{\circ} \mathrm{C}$, where ohmic resistances becomes dominating from $0.35 \mathrm{~A} \mathrm{~cm}^{-2}$ seen from the linear relation between the current density and the potential above $0.35 \mathrm{~A} \mathrm{~cm}^{-2}$. In this regard, it should be noted that iV-curves of PEMECs in the literature generally are reported linear above $0.35 \mathrm{~A} \mathrm{~cm}^{-2}$. 5-8,11,13-17,25 The constant total cell resistances measured above $0.35 \mathrm{~A} \mathrm{~cm}^{-2}$ found from the EIS data and from the slope of the $\mathrm{iV}$-curves in this work are very similar, since at $53^{\circ} \mathrm{C}$ they are $0.357 \pm 0.009 \Omega \mathrm{cm}^{2}$ and 0.362 $\Omega \mathrm{cm}^{2}\left(\mathrm{R}^{2}=0.9987\right)$, respectively, at $61^{\circ} \mathrm{C}$ they are $0.318 \pm 0.001 \Omega$ $\mathrm{cm}^{2}$ and $0.318 \Omega \mathrm{cm}^{2}\left(\mathrm{R}^{2}=0.9992\right)$, respectively, and at $69^{\circ} \mathrm{C}$ they are $0.304 \pm 0.002 \Omega \mathrm{cm}^{2}$ and $0.307 \Omega \mathrm{cm}^{2}\left(\mathrm{R}^{2}=0.9991\right)$, respectively. This constant total cell resistance means that above this $0.35 \mathrm{~A} \mathrm{~cm}^{-2}$, the effect of the oxygen electrode catalyst is not seen, or in other words: adding a more active catalyst will not improve the performance of this cell.

Equivalent circuit for the PEMEC.-Local minima of $-\mathrm{Z}_{\text {im }}$ at the high frequencies are observed in all the Nyquist plots in Figure 4

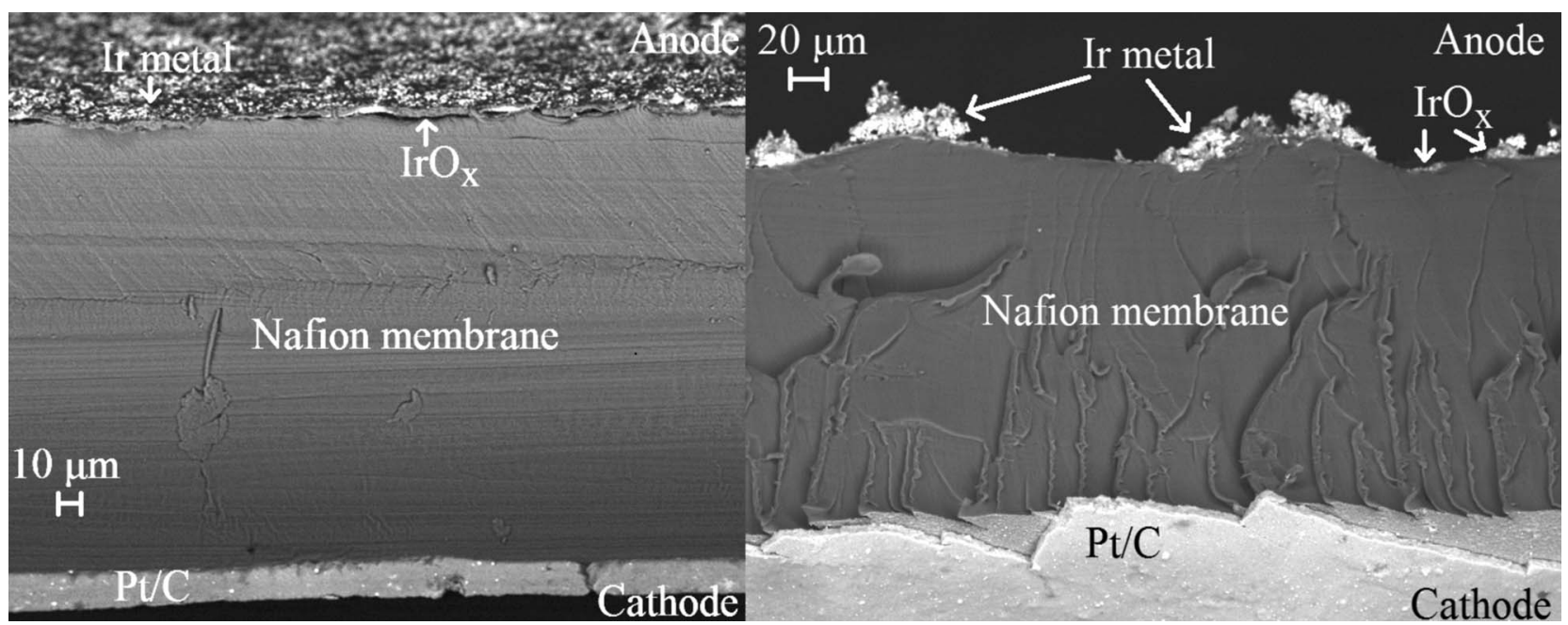

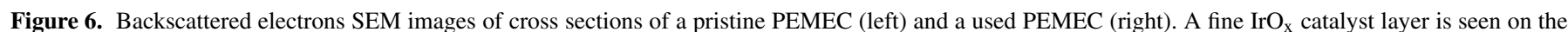

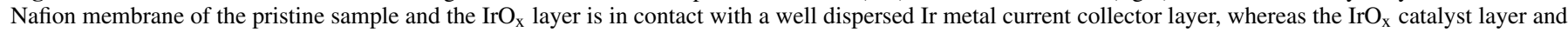
the Ir metal current collector has been peeled off the used PEMEC during detachment of titanium felt after operation. 


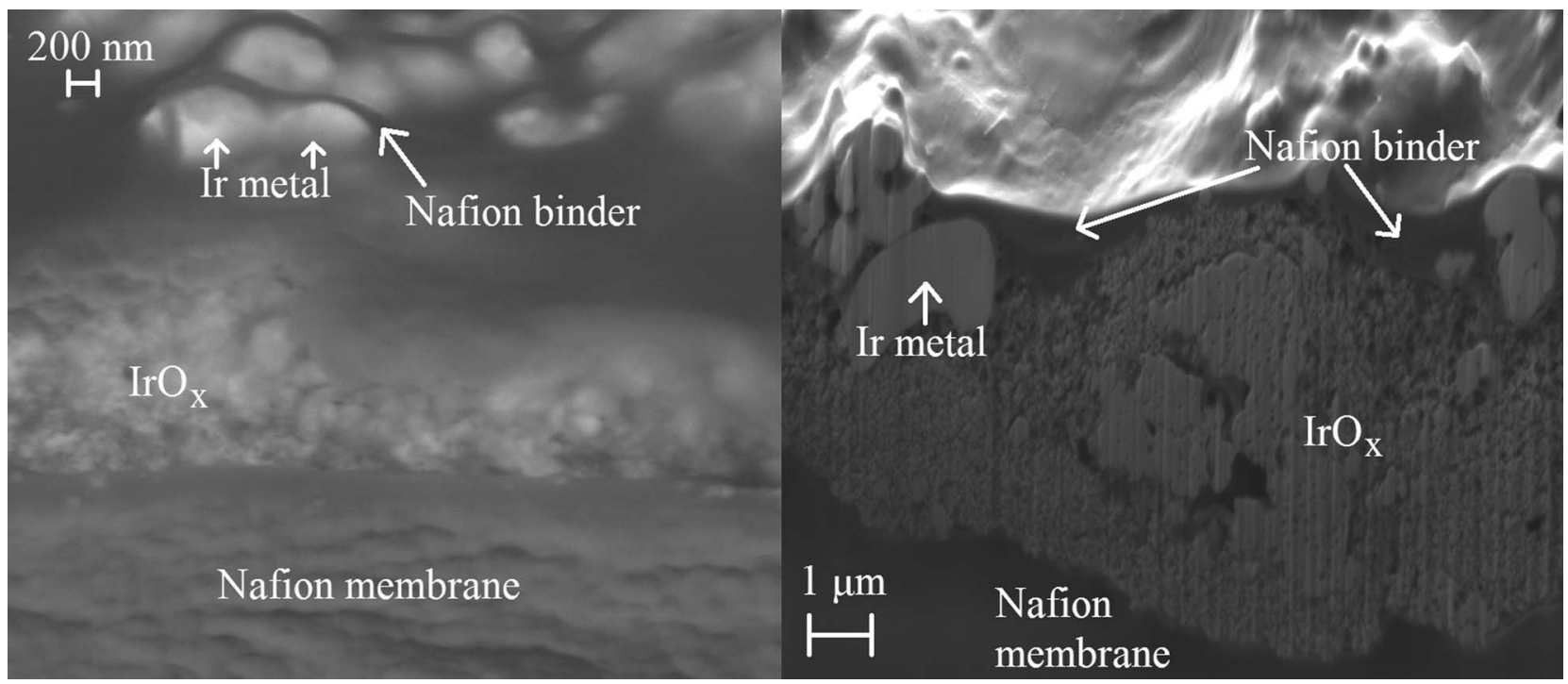

Figure 7. Backscattered electrons SEM image of a cross section of an ionmilled anode of a pristine PEMEC (left) and secondary electrons SEM image of a cross section of the anode of a pristine PEMEC cut with FIB (right). The $\mathrm{IrO}_{\mathrm{x}}$ catalyst layer containing Nafion binder is observed on top of the Nafion membrane. Ir metal particles functioning as current collector are observed on top of the $\mathrm{IrO}_{\mathrm{x}}$ layer. The Ir metal current collector layer does also contain Nafion binder, which is observed as black shadows between the Ir metal particles.

and 5. The real part of the impedance at these local minima are denoted $\mathrm{Z}_{\mathrm{re}, \mathrm{HF} \text { min }}$ and are given in Table III for all three temperatures and four current densities. From Table III it can be seen that $\mathrm{Z}_{\mathrm{re}, \mathrm{HF} \text { min }}$ is not dependent on current density, but dependent of temperature. One could think that $\mathrm{Z}_{\mathrm{re}, \mathrm{HF} \text { min }}$ is the Nafion electrolyte resistance, but this is not the case, since the reported values for $\mathrm{Z}_{\mathrm{re}, \mathrm{HF} \text { min }}$ is slightly higher than the pure electrolyte resistance reported by Malis et al. ${ }^{26}$ They reported conductivity measurements on hydrated Nafion 117 membranes, which prior to EIS examination had been operated in PEMECs, and according to their findings, the membrane resistance should be $0.159 \Omega \mathrm{cm}^{2}$ at $53^{\circ} \mathrm{C}, 0.148 \Omega \mathrm{cm}^{2}$ at $61^{\circ} \mathrm{C}$ and $0.138 \Omega$ $\mathrm{cm}^{2}$ at $69^{\circ} \mathrm{C}$ (calculations can be found in the appendix), which are slightly lower than the $Z_{\text {re, HF min }}$ values found in this work. These findings in the combination with the fact that an increase in $-Z_{\text {im }}$ are observed at the highest frequencies in all the Nyquist plots, cause us to suggest that a third suppressed arc independent on current density is partly observed at the highest frequencies probably originating from current constrictions as described by Fleig et al. ${ }^{27}$ Lettenmeier et al. ${ }^{6}$ observed the same trend with a very high frequency EIS arc independent on current density. Porous nature of the anode or areas with extended electrolyte-electrode contact, causing two-phase boundaries instead of triple phase boundaries in the anode material, may prevent the proton conduction in parts of the electrolyte surface increasing the resistance of the electrolyte. If furthermore big catalyst agglomerates are attached to the electrolyte, these may contribute with a capacitive impedance contribution, which may account for the observed increase in capacitive impedance at the highest frequencies. ${ }^{27}$ Figure 6 depicts SEM images of a pristine and a used PEMEC. A thin, even $\mathrm{IrO}_{\mathrm{x}}$ catalyst layer is observed on the Nafion membrane at the anode of the pristine sample, and a coarse Ir metal current collector layer is observed on top of the $\mathrm{IrO}_{\mathrm{x}}$ layer. The SEM image of the electrochemically tested sample shows a PEMEC with an uneven $\mathrm{IrO}_{\mathrm{x}}$ catalyst layer and an uneven $\mathrm{Ir}$ metal layer. Both the $\mathrm{IrO}_{\mathrm{x}}$ layer and the Ir metal layer contain Nafion binder, which can be observed in the Ir metal layer in Figure 7, where a SEM image of the anode of the pristine sample is depicted. In this image, big Ir metal particles

Table I. Comparison of redox peaks in the CV shown in Figure 2 with redox peaks of iridium oxide at similar conditions in the literature.

Reference

This study

Rozain et al. $^{13}$

Papaderakis et al. ${ }^{4}$

Papaderakis et al. ${ }^{4}$

Ouattara et al. ${ }^{24}$

Ouattara et al. ${ }^{24}$
Experimental conditions

CV measured on a PEMEC consisting of a Nafion 117

membrane and $0.3 \mathrm{mg} \mathrm{cm}^{-2} \mathrm{IrO}_{2}$ and the anode and 0.5 $\mathrm{mg} \mathrm{cm}{ }^{-2} \mathrm{Pt}$ at the cathode. The cathode was flushed with hydrogen.

CV measured on a PEMEC consisting of a Nafion 115 membrane and $0.3 \mathrm{mg} \mathrm{cm}^{-2} \mathrm{IrO}_{2}$ and the anode and

$0.25 \mathrm{mg} \mathrm{cm}^{-2} \mathrm{Pt}$ at the cathode. The cathode was flushed with hydrogen.

$\mathrm{CV}$ of anodically grown $\mathrm{IrO}_{2}$ on an iridium wire measured in deaerated $0.5 \mathrm{M} \mathrm{H}_{2} \mathrm{SO}_{4}$.

$\mathrm{CV}$ of $\mathrm{IrO}_{2} / \mathrm{Nafion}$ electrodes with a catalyst loading of $5-10 \mathrm{mg} \mathrm{cm}^{-2}$ on glassy carbon measured in deaerated $0.5 \mathrm{M} \mathrm{H}_{2} \mathrm{SO}_{4}$.

$\mathrm{CV}$ of anodically grown $\mathrm{IrO}_{2}$ on a metallic iridium electrode in $1 \mathrm{M} \mathrm{H}_{2} \mathrm{SO}_{4}$.

$\mathrm{CV}$ of an anodic iridium film electrode in $1 \mathrm{M} \mathrm{H}_{2} \mathrm{SO}_{4}$.

The film was deposited on $\mathrm{p}-\mathrm{Si}$ by sputtering.
Redox peaks

0.77 and $1.23 \mathrm{~V}$ vs. $\mathrm{H}_{2}$ counter electrode

$0.48,0.80$ and $1.18 \mathrm{~V}$ vs. RHE

$0.50-0.55 \mathrm{~V}$ (Pre ox.), 0.70-0.80 V ( $\mathrm{Ir}^{\mathrm{III}}$ to $\left.\mathrm{Ir}^{\mathrm{IV}}\right), 1.15 \mathrm{~V}$ $\left(\mathrm{Ir}^{\mathrm{IV}}\right.$ to $\left.\mathrm{Ir}^{\mathrm{V}}\right)$ vs. $\mathrm{Ag} / \mathrm{AgCl}$ corresponding to $0.73-0.78 \mathrm{~V}$ (Pre ox.), 0.93-1.30 V ( $\operatorname{Ir}^{\mathrm{III}}$ to $\left.\mathrm{Ir}^{\mathrm{IV}}\right), 1.38 \mathrm{~V}\left(\mathrm{Ir}^{\mathrm{IV}}\right.$ to $\left.\mathrm{Ir}^{\mathrm{V}}\right)$ vs. SHE

$0.70 \mathrm{~V}\left(\mathrm{Ir}^{\mathrm{III}}\right.$ to $\left.\mathrm{Ir}^{\mathrm{IV}}\right)$ and $1.07 \mathrm{~V}\left(\mathrm{Ir}^{\mathrm{IV}}\right.$ to $\left.\mathrm{Ir}^{\mathrm{V}}\right) \mathrm{vs}$.

$\mathrm{Ag} / \mathrm{AgCl}$ corresponding to $0.93 \mathrm{~V}$ ( $\mathrm{Ir}^{\mathrm{III}}$ to $\mathrm{Ir}^{\mathrm{IV}}$ ) and 1.3 $\mathrm{V}\left(\mathrm{Ir}^{\mathrm{IV}}\right.$ to $\left.\mathrm{Ir}^{\mathrm{V}}\right)$ vs. SHE

0.65-0.70 V (Pre ox.), $0.90 \mathrm{~V}$ (Ir ${ }^{\mathrm{III}}$ to $\mathrm{Ir}^{\mathrm{IV}}$ ) and $1.35 \mathrm{~V}$ $\left(\mathrm{Ir}^{\mathrm{IV}}\right.$ to $\left.\mathrm{Ir}^{\mathrm{V}}\right)$ vs. SHE

$0.70 \mathrm{~V}$ (Pre ox.), $0.90 \mathrm{~V}\left(\mathrm{Ir}^{\mathrm{III}}\right.$ to $\left.\mathrm{Ir}^{\mathrm{IV}}\right)$ and $1.35 \mathrm{~V}\left(\mathrm{Ir}^{\mathrm{IV}}\right.$ to $\mathrm{Ir}^{\mathrm{V}}$ ) vs. SHE 
Table II. Total cell resistance measured at the lowest frequency $(0.01 \mathrm{~Hz})$ at 53,61 and $69^{\circ} \mathrm{C}$ and at $0.07,0.35,0.69$ and $1.00 \mathrm{~A} \mathrm{~cm}{ }^{-2}$.

\begin{tabular}{cccccc} 
Temperature $\left[{ }^{\circ} \mathrm{C}\right]$ & $0.07 \mathrm{~A} \mathrm{~cm}^{-2}\left[\Omega \mathrm{cm}^{2}\right]$ & $0.35 \mathrm{~A} \mathrm{~cm}^{-2}\left[\Omega \mathrm{cm}^{2}\right]$ & $0.69 \mathrm{~A} \mathrm{~cm}^{-2}\left[\Omega \mathrm{cm}^{2}\right]$ & $1.00 \mathrm{~A} \mathrm{~cm}^{-2}\left[\Omega \mathrm{cm}^{2}\right]$ & $\begin{array}{c}\text { Average of numbers } \\
\text { marked } *\left[\Omega \mathrm{cm}^{2}\right]\end{array}$ \\
\hline 53 & 0.560 & $* 0.353$ & $* 0.369$ & $* 0.349$ & $0.357 \pm 0.009$ \\
61 & 0.538 & $* 0.319$ & $* 0.317$ & $* 0.319$ & $0.318 \pm 0.001$ \\
69 & 0.519 & $* 0.303$ & $* 0.303$ & $* 0.307$
\end{tabular}

are observed on top of a very porous $\mathrm{IrO}_{\mathrm{x}}$ layer. It is not possible to see the Nafion binder in the $\mathrm{IrO}_{\mathrm{x}}$ layer, which may be ascribed to the very small particle size of approximately $9 \mathrm{~nm}$ of the $\mathrm{IrO}_{\mathrm{x}}$ particles according to EWII Fuel Cells A/S. It should be noted that the titanium felt, which is used as current collector at the anode, is placed on top of the anode of the pristine sample prior to operation. After operation, the titanium felt detaches the PEMEC when disassembling the cell, and the SEM images in Figure 6 may suggest the $\mathrm{IrO}_{\mathrm{x}}$ and $\mathrm{Ir}$ metal to be detached from the Nafion membrane by the titanium felt after operation. The easy detachment of the $\mathrm{IrO}_{\mathrm{x}}$ and $\mathrm{Ir}$ metal layers may suggest bad contact between the Nafion membrane and the $\mathrm{IrO}_{\mathrm{x}}$ layer and the Ir metal layer, which may cause current constrictions at the $\mathrm{Nafion} / \mathrm{IrO}_{\mathrm{x}}$ interface and support the assumption that the increase in $-Z_{\mathrm{im}}$ at very high frequencies is due to current constrictions.

As earlier described, the Nyquist plots in Figure 4 and 5 show an increase of the low frequency arc and a decrease of the middle frequency arc with increasing current density. This trend is also seen in literature by Lettenmeier et al. ${ }^{6}$ and Steen et al. ${ }^{12}$ Furthermore we, as well as Lettenmeier et al., ${ }^{6}$ see no change in total cell impedance with increasing current density at current densities in the linear region of the iV-curve. This implies that the sum of resistances of the low and middle frequency arcs in the Nyquist plots of the impedance of the PEMEC during OER are constant at current densities from $0.35 \mathrm{~A} \mathrm{~cm}^{-2}$ to $1.00 \mathrm{~A} \mathrm{~cm}^{-2}$. These findings imply that the low and middle frequency arcs originate from the composite $\mathrm{IrO}_{\mathrm{x}} / \mathrm{Nafion}$ anode causing two capacitive impedances dependent on current density, but with a total resistive impedance of the two processes independent on current density. The sum of the resistances of the low and middle frequency arcs are given by the difference between the total cell resistance and $\mathrm{Z}_{\mathrm{re}, \mathrm{HF} \text { min }}$, and is given in Table IV. It is seen that the resistance of these two arcs, is approximately $1 / 3$ of the total cell resistance.

Figure 8 depicts a graph of the average $Z_{\mathrm{re}, \mathrm{HF} \text { min }}$ and the average total cell resistance obtained from the EIS data as function of cell temperature including error bars of the standard deviations given in Table II and III and a linear regression of the points. From the graph it is found that $Z_{\mathrm{re}, \mathrm{HF} \text { min }}$ decreases $2.14 \mathrm{~m} \Omega \mathrm{cm}^{2}$ per degree increase in temperature and that the total cell resistance decreases $3.29 \mathrm{~m} \Omega \mathrm{cm}^{2}$ per degree increase in temperature. These results are in the Figure 8 compared to the decrease in in-plane Nafion 117 membrane resistance of $1.31 \mathrm{~m} \Omega \mathrm{cm}^{2}$ per degree increase in temperature reported by Malis et al. ${ }^{26}$ The decrease in resistance with temperature for the total cell resistance, $Z_{\mathrm{re}, \mathrm{HF} \text { min }}$ and the literature values for the in-plane Nafion 117 membrane resistance is in the same order of magnitude, and this may imply that all the resistive impedance contributions in the PEMEC originate from Nafion in the electrolyte and in the electrodes. When comparing the average values of the resistances of the low and middle frequency arcs in Table IV at 53 and $61^{\circ} \mathrm{C}$, a decrease in resistance of $2.13 \mathrm{~m} \Omega \mathrm{cm}^{2}$ per degree increase in cell temperature is found. This dependence is of the same order of magnitude as reported for the total cell resistance, $\mathrm{Z}_{\mathrm{re}, \mathrm{HF} \text { min }}$ and for the literature values for the in-plane Nafion 117 membrane resistance in Figure 8. This indicates that the resistance of the low and middle frequency arcs originates from the Nafion binder in the anode catalyst material. The average resistance of the low and middle frequency arcs measured at $69^{\circ} \mathrm{C}$ does not show the same relation between temperature and resistance as the resistances of the two arcs at 53 and $61^{\circ} \mathrm{C}$, and it is assumed that the measurements at $69^{\circ} \mathrm{C}$ are "outliers".

These findings cause us to suggest an equivalent circuit for the PEMEC consisting of a serial electrolyte resistance obtained from the literature values reported by Malis et al., ${ }^{26}$ a high frequency arc originating from current constrictions at the electrolyte and electrode interface and two low and middle frequency arcs originating from the composite $\mathrm{IrO}_{x} / \mathrm{Nafion}$ anode. Therefore, the equivalent circuit is suggested to be $R-R_{1} Q_{1}-R_{2} Q_{2}-R_{3} Q_{3}$. Summit frequencies of the arcs in Figure 4 and 5 are obtained by fitting the EIS data measured from $0.35 \mathrm{~A} \mathrm{~cm}^{-2}$ to the equivalent circuit $\mathrm{R}-\mathrm{R}_{1} \mathrm{Q}_{1}-\mathrm{R}_{2} \mathrm{Q}_{2}-\mathrm{R}_{3} \mathrm{Q}_{3}$. The EIS data obtained at $0.07 \mathrm{~A} \mathrm{~cm}^{-2}$ at frequencies above $5000 \mathrm{~Hz}$ have been fitted to a slightly different equivalent circuit, which was $R-R_{1} Q_{1}-R_{2} Q_{2}$, since the contribution of the high frequency arc was too small to fit at this low current density. A better fit was obtained, when excluding the very high frequency arc from the calculations, leading to more accurate summit frequency determinations of the middle and low frequency arcs. In this regard it should be noted that the equivalent circuits are only applied to determine summit frequencies, and no further quantifications are done from these fits. The summit frequencies of the middle frequency and low frequency data arcs were found to be $9.10 \mathrm{~Hz}$ and $0.017 \mathrm{~Hz}$, respectively, at $0.07 \mathrm{~A} \mathrm{~cm}^{-2}, 67.2$ $\mathrm{Hz}$ and $0.050 \mathrm{~Hz}$, respectively, at $0.35 \mathrm{~A} \mathrm{~cm}^{-2}, 131.7$ and $0.179 \mathrm{~Hz}$, respectively, at $0.69 \mathrm{~A} \mathrm{~cm}^{-2}$ and $137 \mathrm{~Hz}$ and $0.464 \mathrm{~Hz}$, respectively, at $1.00 \mathrm{~A} \mathrm{~cm}^{-2}$.

Anode catalyst layer contributing to the total cell impedance A hypothesis.-A hypothesis, which may explain the origin of the low and middle frequency arcs, is that the composite $\mathrm{IrO}_{\mathrm{x}} / \mathrm{Nafion}$ anode catalyst layer is causing these arcs. The resistive impedance of these two arcs, which is independent on current density, but dependent on temperature, is suggested to originate from the Nafion binder in the catalyst layer, while the capacitive contribution to the impedance of the two arcs is caused by the redox reactions of the $\mathrm{IrO}_{\mathrm{x}}$ anode catalyst. Kötz et al. ${ }^{28}$ have examined the reaction mechanism of the OER on an $\mathrm{IrO}_{\mathrm{x}}$ catalyst in acidic media with X-ray photoelectron spectroscopy (XPS). They found the Ir in the oxidation states IV, V and VI during the catalytic reaction cycle. Based on their findings, the middle frequency arc is ascribed to oxidation of $\mathrm{Ir}^{\mathrm{IV}}$ to $\mathrm{Ir}^{\mathrm{V}}$ and the arc at the lowest frequencies is ascribed to the oxidation of $\mathrm{Ir}^{\mathrm{V}}$ to $\mathrm{Ir}^{\mathrm{VI}}$, since the higher the potential the more likely the redox specie is in a higher oxidation state, and the low frequency arc is increasing with increasing current density/electrode potential, whereas the middle frequency arc is decreasing with increasing current density/electrode potential. Since the observed $Z_{r e, H F m i n}$ is considered to arise from resistance of the Nafion membrane and from current constrictions at the Nafion

Table III. $\mathrm{Z}_{\mathrm{re}, \mathrm{HF} \min }$ at 53,61 and $69^{\circ} \mathrm{C}$ and at $0.07,0.35,0.69$ and $1.00 \mathrm{~A} \mathrm{~cm}-2$.

\begin{tabular}{ccccrr} 
Temperature $\left[{ }^{\circ} \mathrm{C}\right]$ & $0.07 \mathrm{~A} \mathrm{~cm}^{-2}\left[\Omega \mathrm{cm}^{2}\right]$ & $0.35 \mathrm{~A} \mathrm{~cm}^{-2}\left[\Omega \mathrm{cm}^{2}\right]$ & $0.69 \mathrm{~A} \mathrm{~cm}^{-2}\left[\Omega \mathrm{cm}^{2}\right]$ & $1.00 \mathrm{~A} \mathrm{~cm}{ }^{-2}\left[\Omega \mathrm{cm}^{2}\right]$ & 0.247 \\
\hline 53 & 0.242 & 0.242 & 0.245 & 0.224 & 0.225 \\
61 & 0.225 & 0.224 & 0.222 & 0.002 \\
69 & 0.210 & 0.208 & 0.210 & 0.211
\end{tabular}


Table IV. Resistance of the low and middle frequency arcs found as the difference between the total cell resistance and $\mathrm{Z}_{\mathrm{re}, \mathrm{HF}}$ min at 53,61 and $6^{\circ} \mathrm{C}$ and at $0.07,0.35,0.69$ and $1.00 \mathrm{~A} \mathrm{~cm}^{-2}$.

\begin{tabular}{cccccc} 
Temperature $\left[{ }^{\circ} \mathrm{C}\right]$ & $0.07 \mathrm{~A} \mathrm{~cm}^{-2}\left[\Omega \mathrm{cm}^{2}\right]$ & $0.35 \mathrm{~A} \mathrm{~cm}^{-2}\left[\Omega \mathrm{cm}^{2}\right]$ & $0.69 \mathrm{~A} \mathrm{~cm}^{-2}\left[\Omega \mathrm{cm}^{2}\right]$ & $1.00 \mathrm{~A} \mathrm{~cm}^{-2}\left[\Omega \mathrm{cm}^{2}\right]$ & $\begin{array}{c}\text { Average of numbers } \\
\mathrm{marked}^{2}\left[\Omega \mathrm{cm}^{2}\right]\end{array}$ \\
\hline 53 & 0.318 & $* 0.111$ & $* 0.124$ & $* 0.102$ & $0.112 \pm 0.009$ \\
61 & 0.313 & $* 0.095$ & $* 0.095$ & $* 0.094$ & $0.095 \pm 0.000$ \\
69 & 0.309 & $* 0.095$ & $* 0.093$ & $* 0.096$
\end{tabular}

membrane/electrode interface, this hypothesis implies that the total differential cell polarization resistance (which is equal to the $Z_{\mathrm{re}}$ intercept with the real axis, which again is equal to the slope of the linear part of the iV-curve) at current densities above $0.35 \mathrm{~A} \mathrm{~cm}^{-2}$ can be ascribed only to the proton resistance of Nafion in the electrolyte and in the electrodes. 44.5-46.5\% (resistance of a Nafion 117 membrane reported by Malis et al. ${ }^{26}$ divided by the total cell resistance determined by EIS in this study) of the total cell resistance is ascribed to the proton resistance in the Nafion electrolyte and 53.5-55.5\% (the resistance of the three arcs in the Nyquist plots) is ascribed to the proton resistance in the anode catalyst layer and to current constriction at the electrode/electrolyte interface.

\section{Conclusions}

This study presents a hypothesis that the $\mathrm{IrO}_{\mathrm{x}}$ anode catalyst layer, current constrictions in the Nafion membrane at the electrolyte/electrode interface and the electrolyte resistance of the Nafion membrane are accounting for the total PEMEC impedance above 0.35 $\mathrm{A} \mathrm{cm}^{-2}$, in the linear region of the $\mathrm{iV}$-curve. Linear $\mathrm{iV}$-curves were found at current densities above $0.35 \mathrm{~A} \mathrm{~cm}^{-2}$ at 53,61 and $69^{\circ} \mathrm{C} \mathrm{im}-$ plying the total differential cell resistance to be constant above 0.35 $\mathrm{A} \mathrm{cm}{ }^{-2}$, which is consistent with EIS measurements. The total differential cell area specific resistance obtained from the $\mathrm{iV}$-curves was found to vary from $0.362 \Omega \mathrm{cm}^{2}$ at $53^{\circ} \mathrm{C}$, to $0.307 \Omega \mathrm{cm}^{2}$ at $69^{\circ} \mathrm{C}$. $44.5-46.5 \%$ of the total cell resistance has been ascribed to proton resistance in the Nafion electrolyte and 53.5-55.5\% of the total cell resistance has been ascribed to proton resistance in the $\mathrm{IrO}_{\mathrm{x}} / \mathrm{Nafion}$ composite anode catalyst layer and current constrictions associated with the electrodes. This hypothesis implies that the total differential

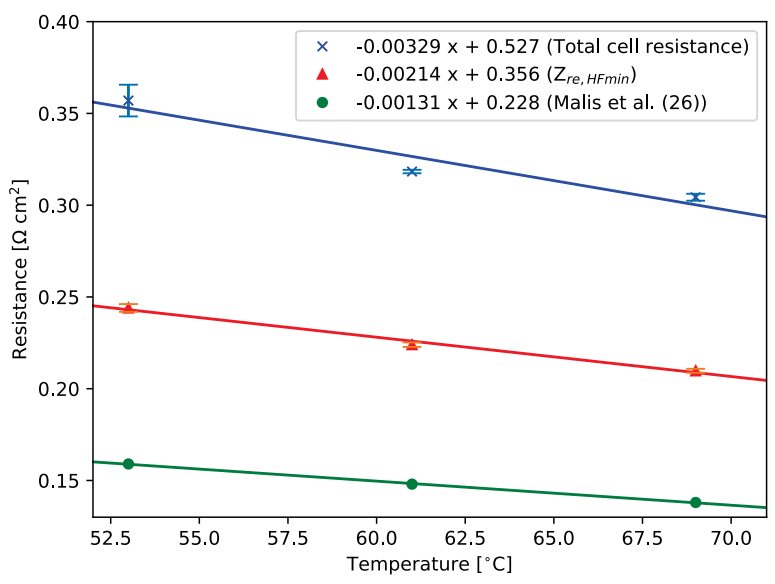

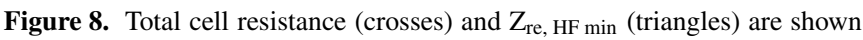
as function of operating temperature. The plotted data is deduced from the EIS data shown in Figure 4 and is also given in Table II and III, respectively. The plotted values are average values determined at $0.35,0.69$ and $1.00 \mathrm{~A} \mathrm{~cm}^{-2}$ and at ambient conditions at the cathode while flushing the anode with 450 $\mathrm{mL} \mathrm{min}^{-1}$ aerated $\mathrm{mQ}$ water at ambient pressure. The results are compared to in-plane resistance measurements of operated Nafion 117 membranes reported by Malis at al. ${ }^{26}$ (circles). cell resistance of the PEMEC is purely ascribed to Nafion at current densities above $0.35 \mathrm{~A} \mathrm{~cm}^{-2}$ for this type of PEMEC.

\section{Acknowledgments}

This work has been performed as part of a $\mathrm{PhD}$ project, which is part of the e-STORE project with contract no. 4106-00025B funded by the Innovation Fund Denmark.

\section{Appendix: Calculations of the Area Specific Resistance of the Nafion 117 Membrane}

The area specific resistance of the Nafion 117 membrane is calculated based on inplane conductivity measurements of a Nafion 117 membrane used for electrolysis reported by Malis et al. ${ }^{26}$

First, the average thickness is calculated from the thicknesses reported in Table 1 in Reference 26.

$$
\text { Average thickness }=\frac{(203+211+206+205+209+207) \mu \mathrm{m}}{6}=206.83 \mu \mathrm{m}
$$

Conductivities of the membrane at the three temperatures are read off the graph in Figure 2 in Reference 26. The conductivities were $0.13 \mathrm{~S} \mathrm{~cm}^{-1}$ at $53^{\circ} \mathrm{C}, 0.14 \mathrm{~S} \mathrm{~cm}^{-1}$ at $61^{\circ} \mathrm{C}$ and $0.15 \mathrm{~S} \mathrm{~cm}^{-1}$ at $69^{\circ} \mathrm{C}$. This gives the following values for the ohmic resistance of the Nafion membrane at the three temperatures using the average thickness for the calculations:

$$
\begin{aligned}
& R_{53{ }^{\circ} \mathrm{C}}=\frac{0.020683 \mathrm{~cm}}{0.13 \mathrm{scm}-1}=0.159 \Omega \mathrm{cm}^{2} \\
& R_{61{ }^{\circ} \mathrm{C}}=\frac{0.020683 \mathrm{~cm}}{0.14 \mathrm{~s} \mathrm{~cm}-1}=0.148 \Omega \mathrm{cm}^{2} \\
& R_{69{ }^{\circ} \mathrm{C}}=\frac{0.020683 \mathrm{~cm}}{0.15 \mathrm{sm}^{-1}}=0.138 \Omega \mathrm{cm}^{2}
\end{aligned}
$$

\section{ORCID}

K. Elsøe (D) https://orcid.org/0000-0002-7316-8053

J. Hjelm (1D https://orcid.org/0000-0003-0072-5784

M. B. Mogensen (D) https://orcid.org/0000-0002-0902-0580

\section{References}

1. M. Carmo, D. L. Fritz, J. Mergel, and D. Stolten, Int. J. Hydrogen Energ., 38, 4901 (2013).

2. A. Lasia, Electrochemical Impedance Spectroscopy and its Applications, chapter 9, Springer, London (2014)

3. S. H. Jensen, A. Hauch, P. V. Hendriksen, M. B. Mogensen, N. Bonanos, and T. Jacobsen, J. Electrochem. Soc., 154, B1325 (2007).

4. A. Papaderakis, D. Tsiplakides, S. Balomenou, and S. Sotiropoulos, J. Electroanal. Chem., 757, 216 (2015).

5. S. Siracusano, V. Baglio, A. Di Blasi, N. Briguglio, A. Stassi, R. Ornelas, E. Trifoni, V. Antonucci, and A. S. Arico, Int. J. Hydrogen Energ., 35, 5558 (2010).

6. P. Lettenmeier, S. Kolb, F. Burggraf, A. S. Gago, and K. A. Friedrich, J. Power Sources, 311, 153 (2016)

7. I. Dedigama, P. Angeli, K. Ayers, J. B. Robinson, P. R. Shearing, D. Tsaoulidis, and D. J. L. Brett, Int. J. Hydrogen Energ., 39, 4468 (2014).

8. J. van der Merwe, K. Uren, G. van Schoor, and D. Bessarabov, Int. J. Hydrogen Energ., 39, 14212 (2014).

9. M. Bernt and H. A. Gasteiger, J. Electrochem. Soc., 163, F3179 (2016).

10. C. Rakousky, U. Reimer, K. Wippermann, M. Carmo, W. Lueke, and D. Stolten, J. Power Sources, 326, 120 (2016).

11. S. Sun, Z. Shao, H. Yu, G. Li, and B. Yi, J. Power Sources, 267, 515 (2014) 
12. S. M. Steen and F. Y. Zhang, J. Phys. Conf. Ser, 548, (2014).

13. C. Rozain, E. Mayousse, N. Guillet, and P. Millet, Appl. Catal. B-Environ., 182, 123 (2016).

14. C. Rozain and P. Millet, Electrochem. Acta, 131, 160 (2014).

15. P. Lettenmeier, R. Wang, R. Abouatallah, S. Helmly, T. Morawietz, R. Hiesgen, S. Kolb, F. Burggraf, J. Kallo, A. S. Gago, and K. A. Friedrich, Electrochem. Acta, 210, 502 (2016)

16. S. Siracusano, V. Baglio, F. Lufrano, P. Staiti, and A. S. Aricò, J. Memb. Sci., 448 209 (2013)

17. P. Millet, N. Mbemba, S. A. Grigoriev, V. N. Fateev, A. Aukauloo, and C. Etiévant, Int. J. Hydrogen Energ., 36, 4134 (2011).

18. H. Tawfik, Y. Hung, and D. Mahajan, J. Power Sources, 163, 755 (2007).

19. A. Hermann, T. Chaudhuri, and P. Spagnol, Int. J. Hydrogen Energ., 30, 1297 (2005)
20. J. Rossmeisl, Z. -W. Qu, H. Zhu, G. -J. Kroes, and J. K. Nørskov, J. Electroanal. Chem., 607, 83 (2007).

21. W. Sheng, H. A. Gasteiger, and Y. Shao-Horn, J. Electrochem. Soc., 157, B1529 (2010).

22. J. Suntivich, K. J. May, H. A. Gasteiger, J. B. Goodenough, and Y. Shao-Horn, Science, 334, 1383 (2011)

23. Graves, C. RAVDAV data analysis software, version $0.9 .7,2012$.

24. L. Ouattara and S. Fierro, J. Appl. Electrochem., 39, 1361 (2009).

25. A. T. Marschall, S. Sunde, M. Tsypkin, and R. Tunold, Int. J. Hydrogen Energ., 32, 2320 (2007).

26. J. Malis, P. Mazur, M. Paidar, T. Bystron, and K. Bouzek, Int. J. Hydrogen Energ., 41, 2177 (2016).

27. J. Fleig and J. Maier, J. Electrochem. Soc., 144, L302 (1997).

28. R. Kötz, H. Neff, and S. Stucki, J. Electrochem. Soc., 131, 72 (1984). 